Article

\title{
Poor Returns to Origin-Country Education for Non-Western Immigrants in Italy: An Analysis of Occupational Status on Arrival and Mobility
}

\author{
Ivana Fellini *, Raffaele Guetto and Emilio Reyneri \\ Department of Sociology and Social Research, University of Milano-Bicocca, 20126 Milano, Italy; \\ E-Mails: ivana.fellini@unimib.it (I.F.); raffaele.guetto@unimib.it (R.G.); emilio.reyneri@unimib.it (E.R.) \\ * Corresponding author
}

Submitted: 27 February 2018 | Accepted: 26 April 2018 | Published: 30 July 2018

\begin{abstract}
Previous research on the Italian case has shown that non-Western immigrants are very likely to hold low-qualified jobs and that their occupational mobility chances are rather poor, which suggests low returns to education. In this paper, we investigate whether, and to what extent, immigrants' different areas of origin moderate the returns to educational degrees obtained in the origin country. Data from a survey on the immigrant population (carried out in 2011-2012) are used, and, differently from previous studies, we focus on returns to origin-country education with respect to both the socioeconomic status of the first job found on arrival and the subsequent occupational mobility. The results show that almost all nonWestern immigrants experience remarkably low returns to post-secondary education on their first job. Contrary to other West-European countries, those returns in Italy are only slightly different by area of origin, which suggests that differences in the transferability and quality of skills are scarcely relevant in a strongly segmented labour market. Rather, the modes of labour market insertion-e.g., formal search methods or relying on contacts with natives-have a sizeable impact on the returns. Origin-country post-secondary degrees are also consistently associated with low returns on subsequent mobility, although highly educated immigrants from new EU member states experience higher chances of upward mobility. In line with some recent findings, recognition of educational credentials seems decisive for the very few non-Western immigrants who are able either to access better-qualified jobs on arrival or to improve their occupational status over time.
\end{abstract}

\section{Keywords}

educational credentials; human capital; immigration; labour market; returns to education

\section{Issue}

This article is part of the issue "The Race for Highly-Skilled Workers", edited by Neli Demireva (University of Essex, UK) and Ivana Fellini (University of Milano Bicocca, Italy).

(C) 2018 by the authors; licensee Cogitatio (Lisbon, Portugal). This article is licensed under a Creative Commons Attribution 4.0 International License (CC BY).

\section{Introduction}

The term ethnic penalty refers to the disadvantage immigrants experience in labour market outcomes when compared to natives with similar personal characteristics, and it is found in all Western European receiving countries (Heath \& Cheung, 2007; Kogan, 2006; Reyneri \& Fullin, 2011). Among the major sources of this penalty, several studies have identified the lower occupational returns to (higher) education as natives holding the same or similar educational attainment benefit from better oc- cupational outcomes in terms both of employment opportunities and of wages or the quality of jobs. Apart from discrimination, the lower returns to education for immigrants are usually explained by the imperfect transferability of human capital from origin to receiving country. Indeed, pre-migration human capital is considered less valuable and therefore less productive than that acquired in the receiving country, because it is supposed to supply either poorer or less-useful skills (Chiswick, 1978; Chiswick \& Miller, 2009a; Friedberg, 2000; Kanas \& Van Tubergen, 2009, 2014; Sanromá, Ramos, \& Simón, 2015). 
More recent studies also emphasize the limited transferability of degrees obtained in different educational systems. Lancee and Bol (2017) show, for instance, that poorer skills explain only one-third of the wage penalty associated with a foreign degree.

A rich body of literature on immigrants' returns to education is available for the US and Canada and a growing body of studies is covering Central and Northern European countries (Basilio, Bauer, \& Kramer, 2017; Hardoy \& Shøne, 2014; OECD, 2014; Prokic-Breuer \& McManus, 2016; Kanas \& van Tubergen, 2009, 2014). However, the Southern European countries are still scarcely considered, despite their prominent role as destinations for international migration flows in recent decades, apart from some attention devoted to Spain (Sanromá et al., 2015; Simón, Ramos, \& Sanromá, 2014).

Building on this literature and on the rich data from a large survey carried out by the Italian National Institute of Statistics (ISTAT) in 2011?2012, we study the returns to origin-country education for immigrants living and working in Italy. Differently from most contributions, we do not make a comparison of the returns to education for immigrants with those for the population born in the country, whose results are now well established. Instead, we focus on how immigrants' different areas of origin affect the returns to origin-country education. Moreover, our paper innovates in two ways on the existing studies, which usually consider the labour market position at the time of the interview. First, we assess the returns with respect to the socioeconomic status of the first job immigrants found on their arrival. Thus, we can overcome a problematic issue common to most studies, namely, the potential effect of the unobservable-or only roughly measurable-work experience that immigrants might have gained in the receiving country as a form of country-specific human capital other than education. Secondly, we analyse the returns to origin-country education on immigrants' subsequent occupational mobility, not only controlling for available measures of country-specific human capital acquisition but also assessing the specific effect of the recognition of the degrees acquired in the origin country, thus contributing to the human capital vs. credentials debate (Lancee \& Bol, 2017).

\section{Why Are Returns to Education for Immigrants so Poor?}

The main explanation for immigrants' poorer returns to education is the limited transferability of the human capital acquired in the origin country (Chiswick, 1978). According to this hypothesis, competencies are countryspecific, such that skills acquired by immigrants in the origin-country educational system do not fit the labour demand in the receiving country and are thus less productive and less rewarded. Yet, the cultural and language distance between origin and receiving countries and the degree of similarity between the educational systems can affect the transferability of skills. Furthermore, immigrants' limited returns to origin-country education might also depend on the lower quality of foreign education and on the worse skills acquired. In particular, several studies show that immigrants educated in non-Western countries hold lower skills than natives and immigrants from Western countries (Bratsberg \& Terrell, 2002; Ferrer \& Riddell, 2008; Kahn, 2004).

A more recent approach, building on the credential theory, also considers the limited transferability of immigrants' educational degrees, net of their skills. Screening theories of education suggest that better-educated individuals perform better in the labour market because employers use education as a signal to proxy workers' unobservable expected productivity (Arrow, 1973; Spence, 1973). According to this perspective, immigrants educated in their origin country hold educational credentials that are poorly valued by employers who are unfamiliar with them. Besides their screening function, educational degrees are formal means to regulate the access to some occupations, especially holding a high socioeconomic status (Collins, 1979). Educational degrees obtained abroad affect immigrants' chances of entering these occupations, because these degrees require formal recognition in the receiving country. Such recognition can entail several long and complex bureaucratic tasks. As a result, immigrants often do not manage to get their credentials recognized, and sometimes they do not even apply for recognition, even when they hold training and skills suitable to enter highly skilled jobs. By preventing immigrants' access to occupations under social closure, the lack of recognition affects the returns to origincountry education. Therefore, both foreign human capital and foreign educational credentials suffer from limited transferability.

As Lancee and Bol (2017) underline, most studies do not distinguish credentialism from the human capital approach. Usually, they only assess the existence of an ethnic penalty, finding that immigrants educated in non-Western countries earn less than natives with the same educational attainment, but they do not explain why (Chiswick \& Miller, 2009b; Ferrer \& Riddell, 2008; Friedberg, 2000). Only rarely do these studies take into account human capital through measures of individual skills (Ferrer, Green, \& Riddell, 2006; Kahn, 2004). Indeed, once the skills are controlled for, the remaining ethnic penalty in returns to origin-country education can be attributed to credentialism. Such is the result of a recent analysis of eleven Western European countries that, accounting for cognitive, non-cognitive and job-specific skills, showed that only approximately one-third of the overall wage penalty associated with a foreign degree can be explained by differences in skills (Lancee \& Bol, 2017). We have no direct measures of skills, but differently from other studies, we consider whether origincountry education has been recognized in the destination country. This allows us to contribute to the human capital vs. credentials debate, as we can analyse the ef- 
fects of recognized degrees both on immigrants' first job in Italy and on subsequent mobility.

Hypotheses on the limited transferability of human capital and of educational degrees do not exhaust all the reasons why immigrants might experience poorer returns to their foreign education. On the one hand, ethnic discrimination could contribute to immigrants' lower wages and/or less-qualified jobs, even after discounting for the lower transferability of skills and credentials. On the other hand, immigrants' self-selection into higher education varies substantially based on the origin country, depending on the level of socio-economic development and the share of population obtaining tertiary education (Barro \& Lee, 2001). Yet, although they are in line with well-established approaches (Heath \& Cheung, 2007), our analyses do not enable account to be taken of the possible effects of discrimination and selectivity and of other unobservable factors of heterogeneity differentiating immigrant workers.

\section{Non-Western Immigrants in the Italian "Low-Skills Equilibrium" Labour Market}

Even more than other Southern European countries, Italy is an interesting case to study the occupational returns to education for highly educated non-Western immigrants because its labour market is characterized by a "lowskills equilibrium" (OECD, 2017), and most of the immigrants who entered the country are poorly educated. This "low-skills equilibrium" results from a labour demand that is greatly skewed towards low-skilled jobs, on the one hand, and from a labour supply where highly educated natives are relatively few, on the other. From the demand side, the reasons are that small firms and family-run businesses dominate the economic fabric and that a "sub-protective" welfare system has produced a large demand for domestic and care work in households (Sciortino, 2004). From the supply side, the reason is an under-financed higher education system, which trains an increasing but still very poor number of highly educated young natives. Such a "low-skills equilibrium", however, is unbalanced, as the demand for poorly skilled jobs largely exceeds the supply of natives prone to enter them. Thus, in line with the cross-national positive correlation between the education of immigrants and that of natives (Banca d'Italia, 2009), Italy is the Western European country that attracts the most poorly educated male and female immigrants from non-Western countries to satisfy its demand for unskilled labour in agriculture, construction, manufacturing and personal services (Kogan, 2014).

The segregation of non-Western immigrants in the secondary labour market of low-skilled jobs is dramatic in Italy (Ballarino \& Panichella, 2015; Fellini, 2018; Fellini \& Guetto, 2018; Fullin \& Reyneri, 2011). The most-recent data from the European Labour Force Survey show that in 2015 , above $57 \%$ of non-Western immigrant men were holding low-skilled manual or non-manual jobs (against the $33 \%$ of men born in the country), a figure that climbs to over $83 \%$ for immigrant women (against one out of three for women born in the country). ${ }^{1}$ This segregation in low-skilled jobs has remained constant over time, notwithstanding the remarkable changes in the composition of immigrants living in Italy. Indeed, within the framework of a highly fragmented geography of origin countries, starting in the 2000s, the foreign-born from Eastern Europe became the large majority, with a leading presence of women in care and domestic work. According to the most-recent data, Romanians represent the largest share of the foreign-born living in Italy (23\%, 57\% of whom are women), followed by Albanians (9\%). With Ukrainians ( $79 \%$ women) and Moldovans (66\% women), they account for more than $40 \%$ of the foreign-born population. Outside Europe, foreign-born from Morocco $(8,7 \%)$, China $(5,4 \%)$, India $(3,3 \%)$ and Philippines $(3 \%)$ are the largest groups.

\subsection{The Hypotheses}

Given these peculiar circumstances, one might wonder whether the returns to origin-country education are very poor or, rather, whether the relative "scarcity" of highly educated immigrants makes their origin-country education especially rewarding. One might also wonder to what extent both the transferability and quality of skills and the educational credentials play a role in differentiating the returns to education for immigrants originating from different areas.

As recent evidence has shown, the huge segregation of non-Western immigrants in low-skilled jobs is the result of both a massive process of occupational status downgrading on arrival-irrespective of immigrants' qualifications in the origin country and despite a slight positive effect of education-and of extremely poor chances of recovery over time, for which the recognition of the origin-country's educational degrees is crucial (Fellini \& Guetto, 2018). In contrast, for immigrants from Western countries, the first job is usually consistent with their qualifications before migration, implying higher returns to education.

If all but Western immigrants experience a strong occupational downgrade with their first job in Italy, irrespective of their occupational attainment in the origin country, we should expect that the returns to origincountry education are rather poor for non-Western immigrants. We should also expect that differences by area of origin, due to differences in transferability and quality of skills, should have little relevance. However, the recognition of educational degrees might be decisive for the very few who access highly skilled jobs already on arrival, in accordance with the credentialism theory. Moreover, if origin-country educational attainment only plays

\footnotetext{
${ }^{1}$ We consider group 5 "Services and Sales Workers", group 6 "Skilled Agricultural, Forestry and Fishery Workers”, group 8 “Plant and Machine Operators and Assemblers", and group 9 "Elementary Occupations" of the International Standard Classification of Occupations (ISCO).
} 
a minor role, we expect that other mechanisms should be relevant for highly educated non-Western immigrants' chances to obtain better jobs on arrival. Better-educated immigrants who rely on co-ethnic contacts for job finding can only access poor job opportunities (bonding social capital). On the contrary, contacts with natives (bridging social capital) or any kind of formal and institutional search method may help them to escape from the "immigrant jobs" trap.

More analytically, focusing on the attainment of a post-secondary degree in the origin country and distinguishing between occupational attainment on arrival and mobility, our first hypothesis and corollaries are as follows:

- H1. Non-Western immigrants experience very poor returns to post-secondary education on their first job on arrival.

- H1a. Such poor returns to origin-country education differ only slightly by area of origin.

- H1b. Recognition of their degree before arrival increases the returns to post-secondary education on the first job.

- H1c. Returns are higher when post-secondary educated immigrants use contacts with natives and formal and institutional search methods to find their first job.

Due to the entrapment in low-skilled jobs and to the narrow occupational mobility between the first job and the current job (Fellini \& Guetto, 2018), the returns to immigrants' post-secondary education are likely to be very poor also for subsequent mobility. However, we do expect such returns to improve over time, especially for those immigrants holding more-transferable and/or higher-quality human capital, net of the acquisition of other forms of country-specific human capital. More specifically, we expect the returns for immigrants from Western and new EU member countries to be higher than for the rest of non-Western immigrants. In line with credentialism theory, we also expect that non-EU immigrants will benefit the most from recognition of their post-secondary degree.

Thus, as regards subsequent mobility, our second hypothesis and corollaries are as follows:

- H2. Non-western immigrants experience very low returns to post-secondary education also with respect to subsequent occupational mobility.

- For Western and New-EU immigrants, however, the returns are higher.

- Non-EU immigrants benefit the most from recognition of their post-secondary degree.
Before shifting to the methodological section, we recall that, consistently with well-established definitions in the sociological literature, we define "returns to education" as the association between educational and occupational attainments (e.g., Shavit \& Müller, 1998). ${ }^{2}$ Consequently, in the empirical analyses, we refer to "poor returns" in case of a weak association between educational attainment and the socioeconomic status of the job.

\section{Data and Methods}

\subsection{The Data and the Sample Selection}

The analysis builds on data from the "Condition and social integration of foreign citizens" survey, carried out by the ISTAT between May 2011 and November 2012 (ISTAT, n.d.). This survey had a target sample of households with at least one immigrant member. These households were located through the municipal registers, with a final sample of 9,553 households and 25,326 interviewees. ${ }^{3}$ Our analysis is carried out on a subsample of 13,557 individuals, including the foreign-born who arrived in Italy between 18 and 54 years of age and who were between 18 and 64 years old at the interview. Among these, we selected the large majority of immigrants having acquired their highest educational degree in their country of birth and who migrated directly from the country of birth to Italy. This was done to discard immigrants who might have acquired additional human capital during previous migratory experiences $(N=12,554)$. This sample is made of people mostly coming from Romania (24.2\%), Albania (9.4\%) and Morocco (9.4\%), followed by Ukraine (5.3\%), China (3.6\%), Moldova (3.3\%) and the Philippines (2.9\%). The sample perfectly reflects the composition by country of origin of the foreign-born population in Italy. The average length of stay is 10.2 years, with $24.1 \%$ of the sample living in Italy 5 years or less and $9.3 \% 20$ years or more. The final sample, of course, only includes those who have had at least one job in Italy. Thus, our final sample to analyse the returns to education on the first job in Italy is composed of 10,424 foreign-born, while the sample to analyse the returns to education on the occupational mobility of the foreign-born is made of 8,271 individuals who are employed at interview. Descriptive statistics for the two samples are shown in Annex, Table A1 and $A 3$ specifically.

\subsection{Variables and Model Specification}

We focus on two dependent variables, both based on the 2008 version of the International Socio-Economic Index (ISEI), a well-known standardized score attributed to each occupation combining information on educa-

\footnotetext{
2 Thus, our definition differs from the one originally elaborated by Mincer (1974) in his seminal work, which considers the return to one additional year of education on the logarithm of wages.

${ }^{3}$ The response rate was $85.4 \%$. The sampling followed a two-stage procedure. In the first stage, 7,982 Italian municipalities were selected according to the size of their immigrant population. However, to take into account the higher concentration of immigrants in Northern regions, in the second stage, the sampling over-represented those living in the Southern regions. In the analyses that follow, we address this by applying the appropriate weights provided by ISTAT (n.d.).
} 
tional requirements and potential earnings (Ganzeboom \& Treiman, 1996). The first dependent variable is the 'ISEI of the first job', and it measures occupational attainment on arrival. The variable has been obtained starting from 3-digit ISCO-08 occupational codes and ranges between 15 and 89 . The second dependent variable, measuring occupational mobility, is the 'change in ISEl' that occurred between the first job and the job held at the time of the interview. The choice of ISEI depends on the advantages of using a metric score in terms of statistical modelling and parsimony. However, the metric score avoids the problem of having an arbitrary definition of downgrade and upgrade, which is necessary in case of occupational classes.

The origin-country 'educational attainment' is the main independent variable, operationalized in two versions. The first version is dichotomized into "up to uppersecondary" and "post-secondary", with the latter including both tertiary and post-secondary non-tertiary degrees, regardless of their recognition (Education). In the second version, post-secondary degrees are further dichotomized based on their recognition: when looking at the ISEI of the first job, we consider whether or not the post-secondary degree was recognized already before migration (Recognition_first), while when looking at the change in ISEI that occurred between the first job and the current job, we include among the recognized degrees recognitions obtained after formal request in Italy (Recognition_present). The second independent variable is the 'area of origin', which considers the EU15 countries and other highly developed countries (also referred to as "Western" in what follows and labelled "EU15\&HD" in the figures), Romania, other Eastern European new EU member states, former-Yugoslavian countries and Albania, former-USSR countries, Africa and the Middle East, Asia and Latin America (Origin).

In all models, 'gender', 'age on arrival' and 'work experience in the origin country' (operationalized as "never worked", "highly-", "medium-", and "low-skilled occupation") are included as control variables. Due to the small number of highly educated immigrants for some areas of origin, we did not implement separate models by gender. However, we tested that the main results are valid for both male and female immigrants.

Regarding the estimates of the ISEI of the first job, the models also control for 'time needed for finding the first job' (job found before migration, 1 month, 1 to 3 months, 4 months and over); the 'job finding method' (co-ethnic contact, Italian contact, institutional and formal methods); the 'region of the first job' (Central/Northern or Southern Italy); two dummies for the 'reason for migrating' (economic or family) ${ }^{4}$ and the 'language proficiency on arrival' (not at all, some, good). As regards the estimates of the change in ISEI between the first job and the current job, the models also control for the area of residence at the interview (Central/Northern or Southern Italy). Moreover, they control for an additive index of language proficiency (measured through four items concerning respondents' ability to read, understand, speak, and write in Italian at interview, ranging from 1, not at all, to 4 , very good). Finally, the models control for the ISEI of the first job and the years since migration, a proxy for potential work experience.

The model specification to estimate the returns to post-secondary education on the ISEI of the first job is as follows:

$$
\begin{aligned}
\text { ISEI }_{t} & =(\text { Education } \times \text { Origin })+ \\
& + \text { Labour Market Insertion }+ \\
& + \text { Migration Background }+ \text { Sociodemo }
\end{aligned}
$$

where $t$ represents the time of the first job after migrating, Education $\times$ Origin represents the interaction between the educational attainment in the origin country and the area of origin, and Labour Market Insertion represents the different modes of insertion in the labour market, i.e., the time needed and the method used to find the first job. Migration Background represents another set of variables accounting for the characteristics of migration, such as the reason for migrating, the language proficiency on arrival and the work experience in the origin country, while Sociodemo includes a set of variables for gender, age on arrival and the region of the first job.

The model is estimated in two additional specifications. One includes the interaction between the origincountry education and the area of origin, also considering the recognition of the post-secondary degree (Recognition_first $\times$ Origin) in order to test our hypothesis $\mathrm{H} 1 \mathrm{~b}$. The second is augmented with the interaction between origin-country education and the job finding method in order to test our hypothesis H1c.

As regards the estimates of the returns to postsecondary education on occupational mobility, the model specification is as follows:

$$
\begin{aligned}
\Delta I S E I_{t+1 / t} & =(\text { Education } \times \text { Origin })+ \\
& +I S E I_{t}+Y S M+\text { Language }_{t+1}+ \\
& + \text { Work experience }+ \text { Sociodemo }
\end{aligned}
$$

where $t$ represents the time of the first job, $t+1$ is the time of the interview and $\Delta I S E I_{t+1 / t}$ is the difference between the current and first job ISEI. Education $\times$ Origin represents the interaction between the educational attainment in the origin country and the area of origin, $I S E I_{t}$ represents the ISEI of the first job, YSM represents the years since migration, Language $_{t+1}$ is the language proficiency at the interview, Work experience represents the work experience in the country of origin, and Sociodemo is a set of variables for gender, age on arrival and the area of residence at the interview.

\footnotetext{
${ }^{4}$ Separate dummies identifying the reasons for which immigrants left their origin country were built, with respondents being allowed to choose more than one option. A dummy for those immigrants indicating political and/or religious persecution among the reasons for migrating was not included in the model due to their very poor number in the sample, consistently with the very few refugees living in Italy at the time of the survey.
} 
The model is estimated in an additional specification that includes the interaction between the origincountry education and the area of origin, also considering the recognition of the post-secondary degree (Recognition_present $\times$ Origin) in order to test our hypothesis $\mathrm{H} 2 \mathrm{~b}$.

All models are estimated through ordinary least squares (OLS) with robust standard errors.

\section{The Returns to Origin-Country Education on the First Job in Italy}

The returns to origin-country education on the socioeconomic status of the first job for each immigrant group are shown in Figure 1, where the squares represent the coefficients of the interaction between the attainment of post-secondary education and the area of origin from the estimates of Model 1. As from our definition of returns to education, the smaller the difference in first job ISEI between immigrants with different educational qualifications, the lower the returns to origin-country education on first job.

As Figure 1 shows, with the exception of immigrants from Western countries and, partly, of Latin Americans, the effect of a post-secondary degree on first job ISEI is either null or not statistically significant (immigrants from Asia, post-soviet countries, Albania and former Yugoslavian countries) or is quite limited (approximately 4 ISEI points for immigrants from Romania, other Eastern European countries, Africa and the Middle East). Over- all, the returns to origin-country education on the socioeconomic status of the first job in Italy are rather poor and are only slightly different for immigrants coming from a wide range of areas of origin, which is consistent with our hypotheses $\mathrm{H} 1$ and $\mathrm{H} 1 \mathrm{a}$.

In line with other studies, only foreign-born from Western countries ("EU15\&HD" in Figure 1) benefit substantially from a post-secondary degree, with an effect on the ISEI score of their first job of approximately 18 points, a figure consistent with the return they experienced in their origin country. ${ }^{5}$ Thus, Western/nonWestern differences in first job ISEI are much larger among highly educated immigrants, compared to less educated ones. ${ }^{6}$

Latin Americans seem to be a special case, likely because many immigrants from some Latin-American countries have Italian ascendants. Indeed, even though the returns to post-secondary education are notably lower than those they would benefit from in the origin country (8 and 19 ISEI points, respectively), the "loss" is more moderate than that experienced by immigrants from all other areas, with the exception of other Eastern European immigrants from new EU member states. It should be noted, moreover, that all immigrants show quite similar high returns to education in the last occupation in their origin country (diamonds in Figure 1, with the solid line referring to the average return).

Figure 2 shows results from Model 1 under the specification that interacts the recognition of the postsecondary degree already on arrival with the area of ori-

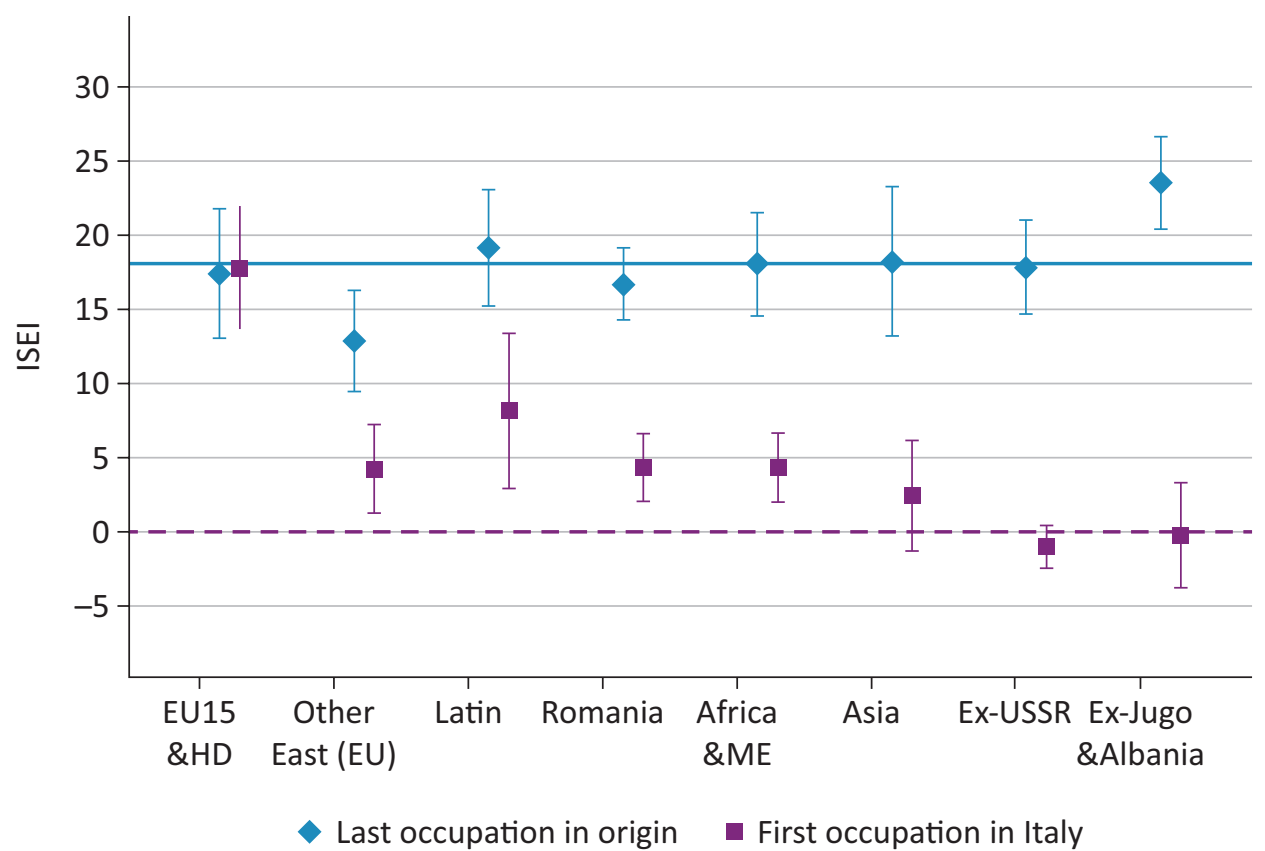

Figure 1. ISEI returns to post-secondary degree by area of origin (controls included, 95\% C.I.).

\footnotetext{
5 To estimate returns to education in the origin country, the sample includes only immigrants with work experience in the origin country who may or may not have worked in Italy.

${ }^{6}$ The average first job ISEI for Western immigrants with up to upper-secondary education predicted based on Model 1 is approximately 35 points, while the same figure ranges between approximately 25 (Asia) and 29 (Ex-USSR) among all other immigrants (full tables available upon request).
} 


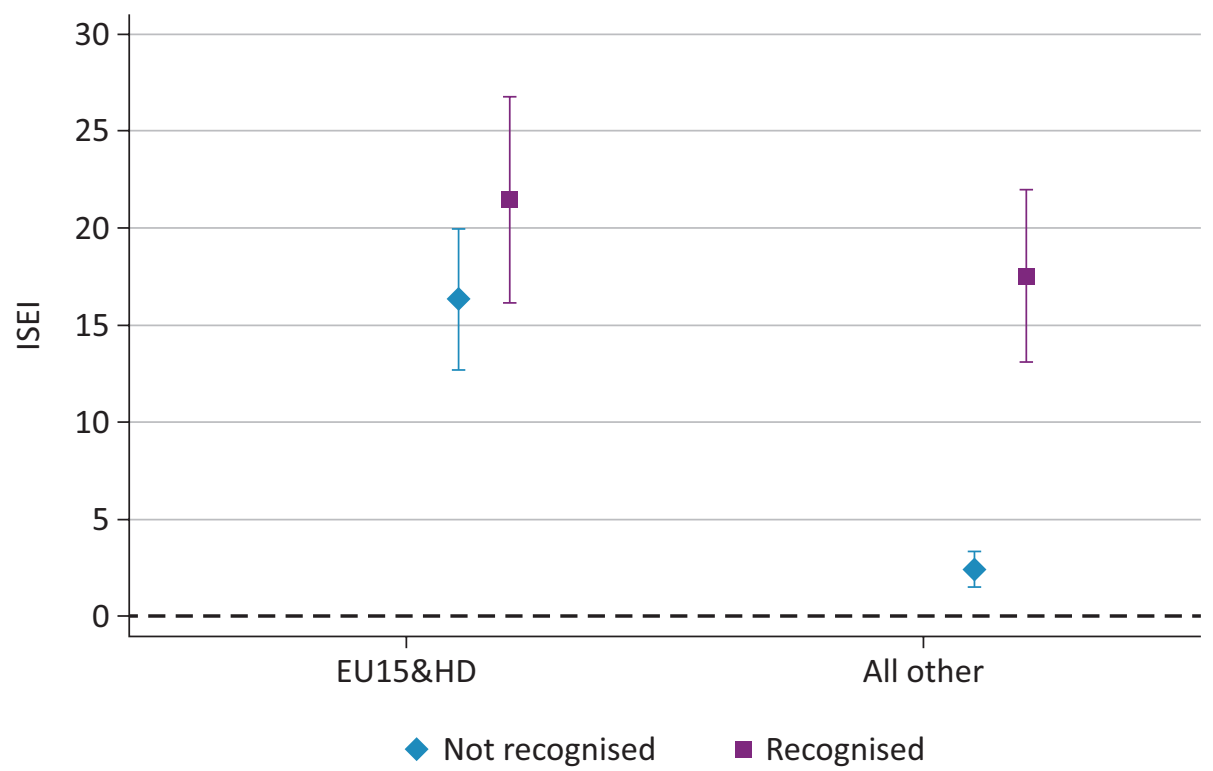

Figure 2. ISEI returns to post-secondary degree on the first job in Italy by origin and recognition (controls included, $90 \%$ C.I.).

gin. Due to the small number of immigrants who have their post-secondary degree recognized on arrival (see table $\mathrm{A} 2$ in Annex), the areas of origin are simplified in a dichotomous variable distinguishing between immigrants from Western countries and those from all other countries. The choice is justified by the fact that returns to education on the first job are only slightly different by area of origin, apart from the Western/non-Western divide (see Figure 1).

As shown in Figure 2, the recognition of the postsecondary degree on arrival seems to play a much more significant role for non-Western immigrants compared to Western ones, for whom the returns to a recognized or not-recognized degree are both high and not significantly different (approximately 21 and 16 ISEI points, respectively). For non-Western immigrants, a non-recognized degree provides extremely low returns (about 2 ISEI points), but the recognition makes them climb to approximately 18 ISEI points, a figure in line with that estimated for Western immigrants. Although consistent with our hypothesis $\mathrm{H} 1 \mathrm{~b}$, it would be hazardous to conclude by this evidence alone that the transferability of credentials is more important than that of skills, let alone that discrimination and other sources of immigrant disadvantage are irrelevant. In fact, we cannot exclude that non-Western immigrants with a degree recognized before arrival differ from other non-Western immigrants on unobservable factors, such as a migratory project that developed in a career perspective more similar to that of many Western foreign-born.

If the returns to immigrants' skills are marginal while the recognition of credentials shows higher returns on the first job, other mechanisms also seem to play a nonnegligible role. Figure 3 plots the coefficients of the interaction between educational attainment and the job finding method, given the different returns to education by area of origin. The focus is on how the effect of holding a post-secondary degree on the ISEI of the first job varies based on the different job finding methods. As expected, a post-secondary degree does not provide any return if the first job is found through co-ethnic contacts, possibly due to the bonding effect of the ethnic social capital (Lancee, 2016). On the contrary, Figure 3 shows that if the first job is found through a personal contact with a native or by relying on either institutional or formal channels (such as employment agencies), post-secondary education provides a statistically significant return of approximately 5 and 8 ISEI points, respectively. The returns to education gained through institutional or formal job finding methods are higher than those granted, on average, by post-secondary education for non-Western immigrants, consistent with our hypothesis H1c.

The relevance of the modes of insertion in the labour market also emerges from the estimates of other factors affecting the ISEI of the first job, as shown in Table 1. Indeed, the relation between the time needed to find the first job and its ISEI shows a U-shaped pattern. The returns are significantly higher when the job is found before arrival or when the job search is longer (4 months and over). This means that both the knowledge of specific job opportunities before migrating and a more selective job search (possibly supported by wider social and economic resources) once in Italy positively affect the socioeconomic status of the first job. Also, Table 1 shows that immigrants who reported having good knowledge of Italian on arrival fare significantly better than those who reported no Italian proficiency (approximately 4 points higher ISEI). Such return is definitely higher than that granted by a non-recognized post-secondary degree (see Figure 2).

The quality of job opportunities for immigrants in Italy strongly depends on the characteristics of the local labour market along a North-South axis (Avola, 2015). Indeed, the ISEI of the first job is, on average, 3 points lower 


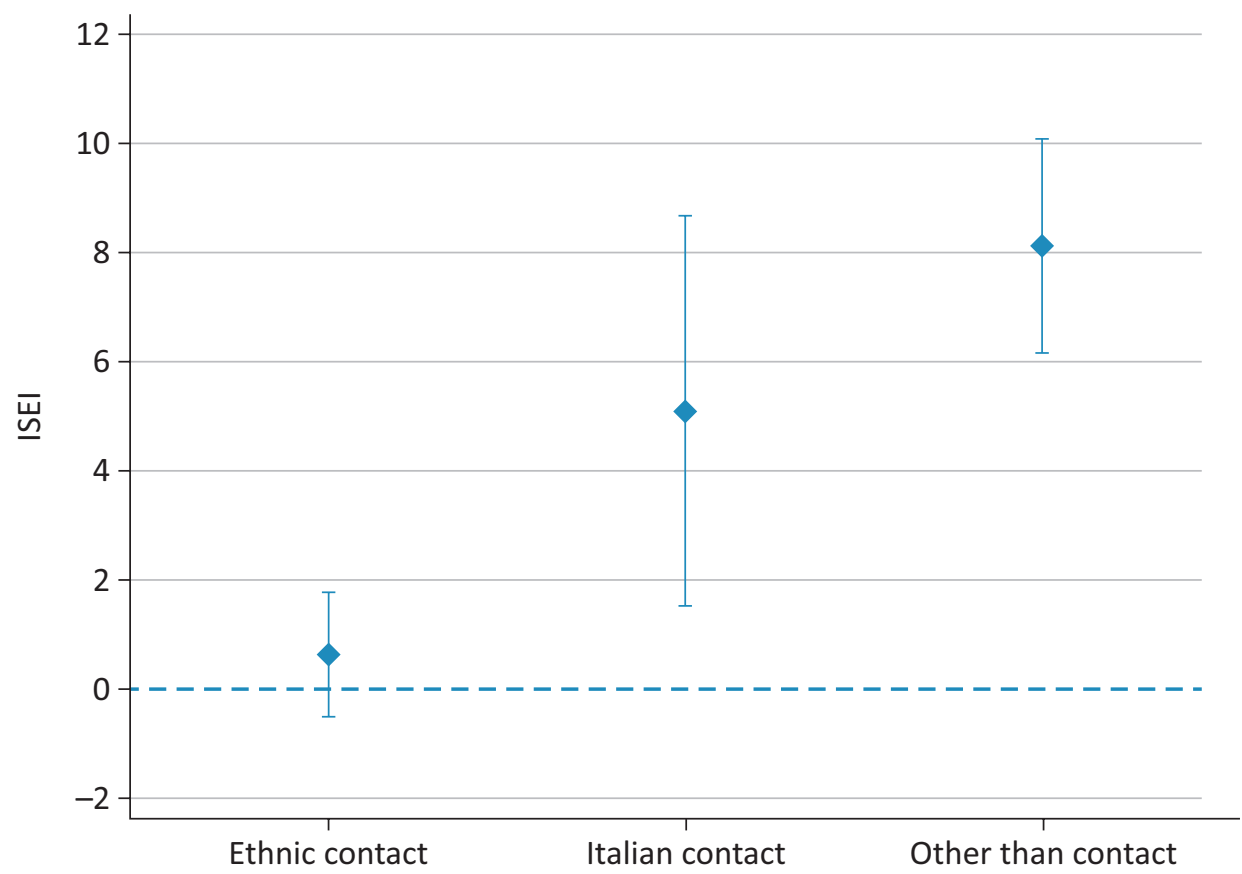

Figure 3. ISEI returns to post-secondary degree on the first job in Italy by job finding method (returns to education by area and other controls included, 95\% C.I.).

Table 1. Factors affecting the ISEI of the first job in Italy (returns to education by area and by job finding method included).

\begin{tabular}{lc}
\hline & Coeff. \\
\hline $1-3$ months of job search (ref. cat.) & - \\
Job found before arrival & $1.124^{*}$ \\
1 month of job search & 0.323 \\
4+ months of job search & $1.169^{* * *}$ \\
\hline Central and Northern Italy (ref. cat.) & - \\
$\quad$ First job found in Southern Italy & $-3.002^{* * *}$ \\
\hline No knowledge of Italian on arrival (ref. cat.) & - \\
$\quad$ Some knowledge & $0.740^{* *}$ \\
$\quad$ Good knowledge & $4.097^{* * *}$ \\
\hline Never worked in origin country (ref.cat.) & - \\
$\quad$ Manager, professional or technician & $2.553^{* * *}$ \\
$\quad$ Clerks, sales and services or skilled manual & $0.607^{* *}$ \\
$\quad$ Agricultural, low- or un-skilled worker & $-1.353^{* * *}$ \\
\hline Economic reason & $-0.613^{* *}$ \\
\hline Family reason & -0.0528 \\
\hline Age on arrival & $-0.0430^{* * *}$ \\
\hline Woman & $-4.852^{* * *}$ \\
\hline Observations & 10,424
\end{tabular}

Note: Robust standard errors $* * * p<0.01, * * p<0.05, * p<0.1$.

in the Southern regions, where immigrants can work almost exclusively in low-skilled jobs in agriculture, construction and personal services.

As regards the role of the migratory background, the work experience in the origin country is relevant. Those who held a managerial, professional or technical position in the last job before migrating, net of other factors, have a significantly higher ISEI for the first job, which is consistent with the hypothesis that on-the-job human capital acquisition positively affects occupational outcomes. In contrast, previous experience in agricultural, low- or unskilled jobs significantly and negatively affects the ISEI 
of the first job. One can argue that experiences in bad jobs, net of other factors, indicate very poor human capital that lowers the thresholds of reservation in accepting job opportunities. Estimates for the reason for migration have to be taken more cautiously due to the way they were collected (see note 4). However, the choice to migrate for economic reasons slightly and negatively affects the ISEI of the first job, while migration for family reasons is not influential. Even though both reasons for migration show an overall limited effect, we can argue that those who migrate in search of a job are likely to be more in need of money than those who migrate to join the family and, consequently, are more pressured to accept whatever job they can find.

Among socio-demographic characteristics, age on arrival has a negative and significant effect, while the disadvantage of immigrant women is remarkable, as the penalization reaches nearly 5 ISEI points. The well-known strongly gendered structure of job opportunities for immigrants in the Italian labour market is connected to the large demand for care and domestic workers, a field targeted at immigrant women (Sciortino, 2004).

\section{The Returns to Origin-Country Education on Occupational Mobility}

The returns to origin-country education on occupational mobility are very poor as well, in line with our hypothesis H2. The estimates of Model 2, reported in Table 2, are based on a simplified definition of the area of origin, aggregating all Eastern European new EU member states and all non-EU countries but Latin American ones, due to the smaller sample size. ${ }^{7}$ The aggregation is consistent with the low differences in returns to education by area of origin shown in Figure 1 . Non-EU immigrants holding a post-secondary degree only gain 1.6 ISEI points between the first job and the job held at the interview, net of all other factors. Thus, the Western/non-Western divide holds as well for the chances of upward mobility, with the immigrants from Western countries showing the highest returns. To a lesser extent, immigrants from New-EU countries and Latin Americans also benefit from returns that are higher than those of other nonEU immigrants, but the difference is significant only for the immigrants from new-EU countries. These results are consistent with our hypothesis $\mathrm{H} 2 \mathrm{a}$.

Table 2. Factors affecting upward mobility in Italy $\left(\triangle I S E I_{t+1 / t}\right)$.

\begin{tabular}{|c|c|}
\hline & Coeff. \\
\hline Post-secondary & $1.630 * * *$ \\
\hline Non-EU (ref. cat.) & - \\
\hline EU15\&HD & $4.202 * * *$ \\
\hline New-EU & 0.124 \\
\hline Latin & -0.0575 \\
\hline Post-secondary*EU15\&HD & $3.772 * *$ \\
\hline Post-secondary*New-EU & $1.901 * *$ \\
\hline Post-secondary*Latin & 1.691 \\
\hline Knowledge of Italian at interview (index) & $0.672 * * *$ \\
\hline YSM & $0.195^{* * *}$ \\
\hline $\mathrm{YSM}^{2}$ & $-0.00394 * *$ \\
\hline Residence in Centre-North at interview (ref. cat.) & - \\
\hline Residence in the South at interview & $-1.097 * * *$ \\
\hline ISEI of 1st job & $-0.349 * * *$ \\
\hline Never worked in origin country (ref.cat.) & - \\
\hline Manager, professional or technician & $2.107 * * *$ \\
\hline Clerks, sales and services or skilled manual worker & $0.517^{*}$ \\
\hline Agricultural, low- or un-skilled worker & 0.0779 \\
\hline Age on arrival & $-0.0689 * * *$ \\
\hline Woman & $-2.770 * * *$ \\
\hline Observations & 8,721 \\
\hline R-squared & 0.186 \\
\hline
\end{tabular}

Note: Robust standard errors $* * * p<0.01,{ }^{* *} p<0.05,{ }^{*} p<0.1$.

\footnotetext{
7 In this model, only immigrants employed at the time of the interview are included.
} 
For non-EU immigrants, recognition of the postsecondary degree is also decisive for their mobility chances, as predicted by our hypothesis $\mathrm{H} 2 \mathrm{~b}$. Figure 4 plots the returns to a post-secondary degree on the change of ISEI between the first job and the current job by origin area and whether or not the degree was recognized at the time of the interview. While having the degree recognized does not make a significant difference for the mobility of immigrants from EU15 or other developed countries and has some significant effects for those from new EU countries, non-EU immigrants experience upward mobility only if their degree is recognized. With recognition of the degree, the returns to education on occupational mobility for non-EU immigrants become as high as those of immigrants from Western and new-EU countries. We have to recall, however, that the share of new-EU and non-EU immigrants in our data with a recognized post-secondary degree at interview is very low $(2.7 \%$ and $1.7 \%$, respectively) in comparison with Western immigrants (32.7\%) so that, even if the effect of recognition is important, non-Western immigrants who benefit from it are very few (see table $A 3$ in Annex).

\section{Conclusions}

The analysis has shown not only that non-Western immigrants encounter extremely poor returns to postsecondary education acquired in the origin country on the first job in Italy but also that these returns are only slightly different by area of origin. This evidence suggests that differences in the transferability and quality of skills-one of the leading hypotheses to account for immigrants' poor returns to education-are scarcely relevant in a strongly segmented labour market such as the Italian one. Returns are actually poor for occupational mobility as well because in this kind of labour mar- ket, non-Western immigrants are trapped in low-skilled jobs, regardless of their human capital. Yet, highly educated immigrants from Eastern European new EU member states experience returns to education on arrival that are closer to those they would have obtained in the origin country. They have especially higher chances of upward mobility between the first job and the current job compared to non-EU immigrants. This may be due to the convergence of the educational systems and the higher mobility of students brought about by the European integration process, which may have increased the transferability of skills and credentials for new EU immigrants.

As regards the first job, managing to find a job through contacts with natives and even more through formal methods proved to be important for highly educated immigrants in order to avoid being channelled into the secondary segment of the labour market. Moreover, recognition of the post-secondary degree already on arrival seems to play a substantial role for the very few non-Western immigrants having that degree recognized. In line with recent findings, the recognition of educational credentials seems decisive as well for the very few non-EU immigrants who can improve their occupational status over time. Hence, even if we cannot properly measure skills, our results seem to be in line with the credential theory, which argues that educational credentials (sheepskin effects) are more important than skills for occupational outcomes.

Our study shows that recognition matters at all stages of the labour market experience of immigrants. Consequently, policies targeted at the recognition of foreign degrees could be as important as training policies addressing immigrants' skills. Nevertheless, other factors have proved to play a significant role in non-EU immigrants' outcomes, net of education and recognition of credentials. The penalization of immigrant women is

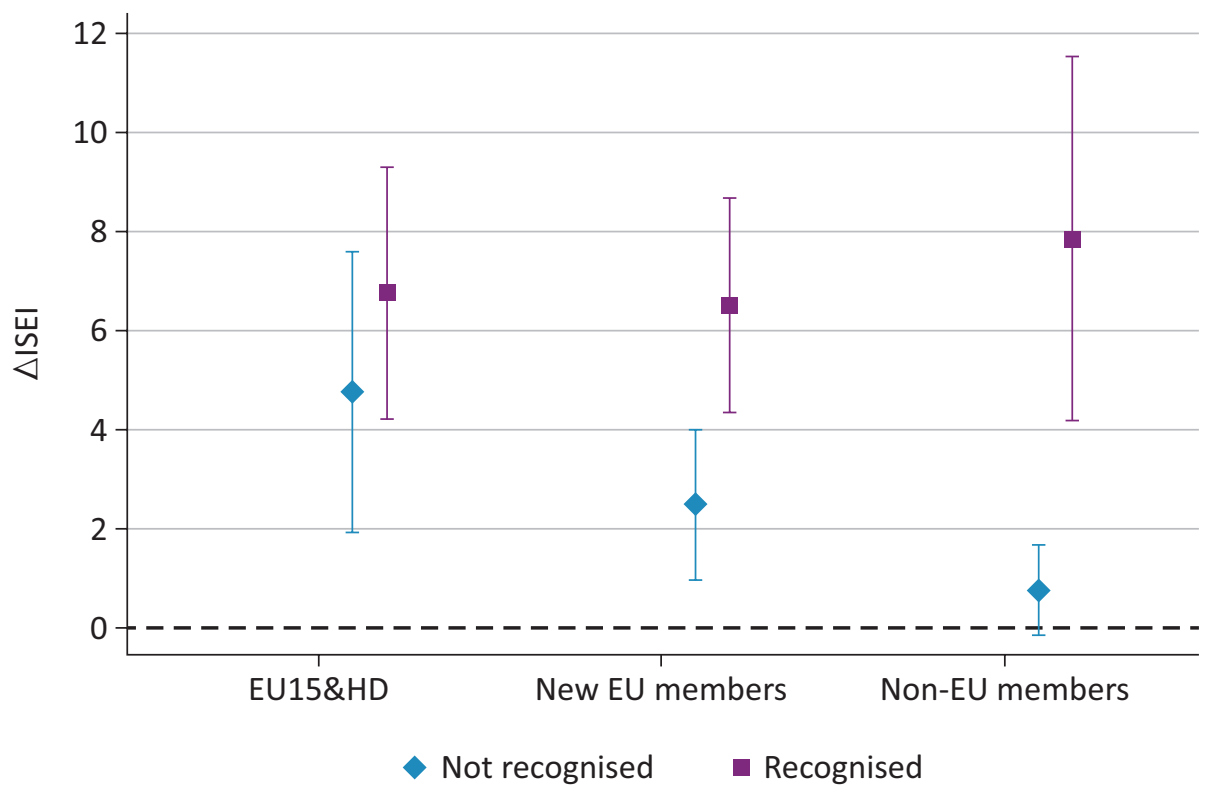

Figure 4. Returns to post-secondary degree by origin and recognition on $\Delta I S E I_{t+1 / t}$ in Italy (Controls included, $90 \%$ C.I.). 
high both on the first job and on subsequent mobility, due to the strongly gendered pattern of immigrants' insertion in the Italian labour market. The structure of opportunities in the local labour market also plays a role, with immigrants in the Southern regions being more penalized. Pre-migration human capital and language proficiency also play a non-negligible role, both for the first job and for mobility opportunities.

\section{Acknowledgments}

This research has been supported by funding from the European Commission (Grant number H2020 649255). The authors also wish to thank the anonymous reviewers and all the participants to the GEMM Project meeting held in Oxford, 30 November-1 December 2017.

\section{Conflict of Interests}

The authors declare no conflict of interests.

\section{References}

Arrow, K. (1973). Higher education as a filter. Journal of Public Economics, 2, 193-216.

Avola, M. (2015). The ethnic penalty in the Italian labour market: A comparison between the centre-north and south. Journal of Ethnic Migration Studies, 41(11), 1746-1768.

Ballarino, G., \& Panichella, N. (2015). The occupational integration of male migrants in western European countries: Assimilation or persistent disadvantage? International Migration, 53(2), 338-352.

Banca d'Italia. (2009). Relazione annuale 2008. Roma: Banca d'Italia.

Barro, R. J., \& Lee, J.-W. (2001). International data on educational attainment: Updates and implications. Oxford Economic Papers, 53(3), 541-563.

Basilio, L., Bauer, T., \& Kramer, A. (2017). Transferability of human capital and immigrant assimilation: An analysis for Germany. Labour, 31(3), 245-264.

Bratsberg, B., \& Terrell, D. (2002). School quality and returns to education of US immigrants. Economic Inquiry, 40(2), 177-198.

Chiswick, B. R. (1978). The effect of Americanization on the earnings of foreign born men. Journal of Political Economy, 86(5), 897-922.

Chiswick, B. R., \& Miller, W. P. (2009a). The international transferability of immigrants' human capital. Economics of Education Review, 28(2), 162-169.

Chiswick, B. R., \& Miller, W. P. (2009b). An explanation for the lower payoff to schooling for immigrants in the Canadian labour market (Discussion Paper). Bonn: IZA.

Collins, R. (1979). The credential society. New York, NY: Academic Press.

Fellini, I. (2018). Immigrants' labour market outcomes in Italy and Spain: Has the southern European model disrupted during the crisis? Migration Studies, 6(1), 53-78.

Fellini, I., \& Guetto, R. (2018). A “U-shaped” pattern of immigrants' occupational careers? A comparative analysis of Italy, Spain, and France. International Migration Review, first published April 2018, 1-33. https://doi.org/10.1177/0197918318767931

Ferrer, A., Green, D. A., \& Riddell, W. C. (2006). The effect of literacy on immigrant earnings. Journal of Human Resources, 41(2), 380-410.

Ferrer, A., \& Riddell, W. C. (2008). Education, credentials, and immigrant earnings. Canadian Journal of Economics, 41(1), 186-216.

Friedberg, R. M. (2000). You can't take it with you? Immigrant assimilation and the portability of human capital. Journal of Labor Economics, 18(2), 221-251.

Fullin, G., \& Reyneri, E. (2011). Low unemployment and bad jobs for new immigrants in Italy. International Migration, 49(1), 118-147.

Ganzeboom, H. B. G., \& Treiman, D. J. (1996). Internationally comparable measures of occupational status for the 1988 international standard classification of occupations. Social Science Research, 25(3), 201-239.

Hardoy, I., \& Shøne, P. (2014). Returns to preimmigration education for non-western immigrants: Why so low? Education Economics, 22(1), 48-72.

Heath, A., \& Cheung, Y. (2007). Unequal chances. Ethnic minorities in western labour markets. Oxford: Oxford University Press.

ISTAT. (n.d.). Social condition and integration of foreign citizens: Microdata for research purposes. Italian National Institute of Statistics. Retrieved from www.istat.it/en/archivio/191097

Kahn, L. M. (2004). Immigration, skills and the labor market: International evidence. Journal of Population Economics, 17(3), 501-534.

Kanas, A., \& Van Tubergen, F. (2009). The impact of origin and host country schooling on the economic performance of immigrants. Social Forces, 88(2), 893-916.

Kanas, A., \& Van Tubergen, F. (2014). The conditional returns to origin-country human capital among Turkish and Moroccan immigrants in Belgium. Social Science Research, 46, 130-141.

Kogan, I. (2006). Labor markets and economic incorporation among recent immigrants in Europe. Social Forces, 85(2), 697-721.

Kogan, I. (2014). Politiche migratorie, processi di selezione e inserimento occupazionale degli immigrati. In P. Barbieri \& G. Fullin (Eds.), Lavoro, istituzioni, diseguaglianze (pp. 71-89). Bologna: II Mulino.

Lancee, B. (2016). Job search methods and immigrant earnings. A Longitudinal analysis of the role of bridging social capital. Ethnicities, 16(3), 349-367.

Lancee, B., \& Bol, T. (2017). The transferability of skills and degrees: Why the place of education affects immigrant earnings, Social Forces, 96(2), 691-716.

Mincer, J. (1974). Schooling, experience and earnings. New York, NY: National Bureau of Economic Research. 
OECD. (2014). Matching economic migration with labour market needs. Paris: OECD Publishing.

OECD (2017). OECD skills strategy diagnostic report: Italy. Paris: OECD Publishing.

Prokic-Breuer, T., \& McManus, P. A. (2016). Immigrant educational mismatch in western Europe, apparent or real? European Sociological Review, 32(3), 411-438.

Reyneri, E., \& Fullin, G. (2011). Labour market penalties of new immigrants in new and old receiving west European countries. International Migration, 49(1), 31-57.

Sanromá, E., Ramos, R., \& Simón, H. (2015). Immigrant wages in the Spanish labour market: How relevant is the origin of human capital? Journal of Applied Eco- nomics, 18(1), 149-172.

Sciortino, G. (2004). Immigration in a Mediterranean welfare state: The Italian experience in comparative perspective. Journal of Comparative Policy Analysis, 6(2), 111-129.

Shavit, Y., \& Müller, W. (1998). From school to work. A comparative study of educational qualifications and occupational destinations. New York, NY: Clarendon Press.

Simón, H., Ramos, R., \& Sanromá, E. (2014). Immigrant occupational mobility: Longitudinal evidence from Spain. European Journal of Population, 30(2), 223-255.

Spence, M. (1973). Job market signalling. Quarterly Journal of Economics, 87(3), 355-374.

\section{About the Authors}
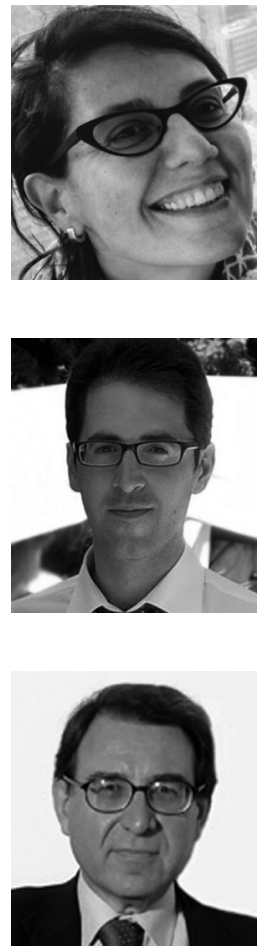

Ivana Fellini, Ph.D. in Sociology and Social Research, is Assistant Professor in Economic Sociology and Sociology of Work at the University of Milano-Bicocca. Her research interests cover labour market trends, employment change and immigrants' incorporation in the labour market. She published several articles in national and international journals, among which Work, Employment \& Society, Migration Studies and International Migration Review.

Raffaele Guetto obtained his Ph.D. in Sociology and Social Research from the University of Trento (2012), where he taught courses on education, social inequality and social policy. He is currently research fellow at the University of Milano-Bicocca. His research interests include social demography, social stratification and inequality, and immigration. His works have been published in European Sociological Review, Journal of Ethnic and Migration Studies, European Journal of Population and International Migration Review.

Emilio Reyneri is Emeritus Professor of Sociology of Work at the Department of Sociology and Social Research, University of Milano-Bicocca, after having been full professor from 1980 to 2013. His main topics of research are labour market, labour policies and migration. He has coordinated several international research projects on migration and has a very rich record of publications among which several books and articles in international leading journals such as Journal of Ethnic and Migration Studies, International Journal of Comparative Sociology, International Migration. 
Annex

Table A1. Descriptive statistics of samples for Model 1 (ISEl first job) and Model 2 (Change in ISEI).

\begin{tabular}{|c|c|c|}
\hline & First job & Transition from first to present job \\
\hline Sample size & 10424 & 8721 \\
\hline \multicolumn{3}{|l|}{ Sex } \\
\hline Male & 49.8 & 52.4 \\
\hline Female & 50.2 & 47.7 \\
\hline Mean age on arrival & 29.1 & 29.3 \\
\hline \multicolumn{3}{|l|}{ Area of origin } \\
\hline EU15 \& other highly developed countries & 3.6 & 3.7 \\
\hline New-EU & & 31.3 \\
\hline Romania & 25.9 & \\
\hline Other East & 5.2 & \\
\hline Non-EU & & 56.2 \\
\hline Ex-Jugo \& Albania & 12.2 & \\
\hline Ex-USSR & 11.0 & \\
\hline Africa \& ME & 20.4 & \\
\hline Asia & 12.9 & \\
\hline Latin & 8.8 & 8.7 \\
\hline Education & (on arrival) & (at interview) \\
\hline No title & 6.9 & 7.0 \\
\hline Upper-secondary not recognised & 79.4 & 75.3 \\
\hline Upper-secondary recognised & 1.5 & 5.3 \\
\hline Post-secondary not recognised & 11.3 & 9.1 \\
\hline Post-secondary recognised & 1.0 & 3.4 \\
\hline \multicolumn{3}{|l|}{ Labour market condition in origin country } \\
\hline Never worked & 35.0 & 34.7 \\
\hline Highly-skilled worker & 14.6 & 14.8 \\
\hline Middle-skilled worker & 34.3 & 33.7 \\
\hline Low-skilled worker & 16.2 & 16.8 \\
\hline Proficiency in Italian & (on arrival) & (at interview) \\
\hline Not at all & 69.2 & 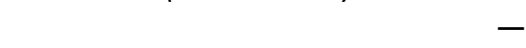 \\
\hline Some & 27.2 & - \\
\hline Good & 3.7 & - \\
\hline Average additive score (1-4) & - & 3.3 \\
\hline \multicolumn{3}{|l|}{ Job finding method } \\
\hline Ethnic contact & 60.3 & - \\
\hline Contact with an Italian & 11.3 & - \\
\hline Other formal/institutional methods & 28.4 & - \\
\hline \multicolumn{3}{|l|}{ Time needed to find job } \\
\hline Job found before arrival & 6.5 & - \\
\hline 1 month of job search & 38.1 & - \\
\hline $1-3$ month of job search & 26.9 & - \\
\hline $4+$ months of job search & 24.6 & - \\
\hline Missing & 3.8 & - \\
\hline Migrating for economic reasons & 64.1 & - \\
\hline Migrating for family reasons & 20.5 & - \\
\hline Territorial area & (of first job) & (residence) \\
\hline Centre-North & 80.9 & 85.1 \\
\hline South & 19.1 & 14.9 \\
\hline Years Since Migration (mean) & - & 10.7 \\
\hline
\end{tabular}




\section{COGITATIO}

Table A2. Descriptive statistics for the interaction term in Figure 2 (area of origin \#\# education at origin).

\begin{tabular}{lrrrr}
\hline & Up to Upper-secondary & Post-secondary not recognised & Post-secondary recognised & Total \\
\hline EU15\&HD & 46.6 & 37.4 & 15.9 & 100.0 \\
All other & 89.3 & 10.3 & 0.4 & 100.0 \\
Total & 87.8 & 11.3 & 1.0 & 100.0 \\
\hline
\end{tabular}

Table A3. Descriptive statistics for the interaction term in Figure 4 (area of origin \#\# education at interview).

\begin{tabular}{lrrrr}
\hline & Up to Upper-secondary & Post-secondary not recognised & Post-secondary recognised & Total \\
\hline EU15\&HD & 42.3 & 25.0 & 32.7 & 100.0 \\
New-EU & 91.3 & 5.9 & 2.7 & 100.0 \\
Non-EU & 88.4 & 10.0 & 100.0 \\
Latin & 87.4 & 8.5 & 1.7 \\
Total & 87.5 & 9.1 & 4.1 & 100.0 \\
\hline
\end{tabular}

